\title{
Australian Franchising Research: Review, synthesis and future research directions
}

Owen Wright, Griffith University, o.wright@ griffith.edu.au Andrew McAuley, Griffith University, a.mcauley@ griffith.edu.au

\begin{abstract}
This paper represents a brief history of the development of franchising in Australia and its regulatory framework and links this to an analysis of relevant research. Findings indicate a disparate ad hoc approach to research including scoping studies at the embryonic stage of franchise development; significant evidence of census style research culminating in a trajectory of disparate studies utilising more sophisticated research methods. For franchising research to advance there appears to be a need to interface with other research domains in SME and entrepreneurship research, extend the range of issues which are the subject of franchising research; begin longitudinal studies in order to better understand change over time; promote studies which have a sectoral focus in order to improve knowledge and understanding at that level of analysis; and, increase the representation of crosscultural research in the volume of work being undertaken.
\end{abstract}

Keywords: franchising, SME, future research directions, cross-cultural research 


\section{Australian Franchising Research: Review, synthesis and future research directions}

\section{Introduction}

The Australian franchising sector is represented by 71,400 franchise system units contributing $\$ 131$ billion in sales of goods and services to Australia's Gross Domestic Product each year (Frazer, Weaven, \& Wright, 2008). Franchising has grown rapidly in the past three decades in Australia (Frazer, Weaven, \& Wright, 2006; Frazer et al., 2008). In order to contextualise this body of research a comprehensive history of franchising and the regulatory regime governing the sector Australia is presented. An extensive review and synthesis then takes place highlighting limited strategic consideration of research in this context. Suggestions are put forward for a future research agenda.

\section{A history of franchising in Australia}

Little franchising was evident in Australia prior to 1970, except for product franchising in the petroleum and motor vehicle industries (McCosker, 1994). The introduction of fast food franchises such as KFC and McDonalds, began a trend in the 1960s and 1970s toward locally based systems which resulting further expansion (Terry, 1996). Increased intensity in business competition during the 1970s and early 1980s resulted in the failure of many small and medium sized businesses and encouraged growth in franchising. This perceived safe alternative to independent operations provided a means for new small business people to benefit from an established business systems and a recognised brand name (Terry, 1991). This growth in franchising was attributed to the absence of intrusive regulatory controls at state or federal level, an increasingly affluent local population and a willingness of the Australian people to accept new ideas and foreign investment (Lim \& Frazer, 2001; Terry, 1996).

Franchising continued to grow at an accelerated rate during the 1980s. This was attributed to an increase in interest from the financial and public sectors. However, media interest in the failure of some high profile franchises prompted questions as to the appropriateness of franchising as a medium of distribution (Frazer, 2000). Although an empirical study by Williams (1992) found that franchise survival rates were greater than those of small business, there was nevertheless a growing interest in consumer protection and sector regulation. Calls for franchising sector regulation led to the formation of the Franchisors Association of Australia in 1981. Later, in 1993, this private association extended its membership to include franchisees and became known as the Franchise Association of Australia and New Zealand (FAANZ). With the growth in its membership and international affiliations, it then became known as the Franchise Council of Australia (FCA) in 1998 (with the New Zealand Chapter forming its own organisation). The aims of the association are to represent equally franchisors, franchisees and other franchising entities including marketing consultants, advisors, solicitors, accountants and brokers (FCA, 2007).

In parallel the legal framework underwent significant development through this same period(Corones, 1999; O.E.C.D., 1994; Terry, 1996). However, little credence is evident in franchising literature of the effects of Australian franchise regulation (Frazer, 2000). Pre-1981, franchising was largely unregulated with no specific statute governing the sector apart from the commonwealth Petroleum Retail Franchise Act 1980 (Terry, 1996; Terry \& Giugni, 2005). Franchise investment was bound by general laws governing commercial trading activity, with most activity occurring under Section 52 of the Trade Practices Act 1974 (Cth) (TPA) where franchisees could seek recourse from franchisors regarding alleged misleading or deceptive conduct (Terry, 1996). In the 1980s sections of the Trade Practices Act (1974) were modified to enhance macroeconomic competition through the facilitation of market access to new products and the promotion of inter-brand competition (Corones, 1999). From 1981 to 1987 a period of quasi-regulation existed, reverting back to a period of deregulation from 1987 to 1993 . From 1993 to 1996 the sector unsuccessfully attempted self regulation thus reverting to deregulation in 1997 and finally to mandatory regulation effective from 1998 (Terry \& Giugni, 2005). This is known as the Franchising Code of Conduct (the Code) in 1998 (Lim \& Frazer, 2001; 
McCosker \& Frazer, 1998). In the Code, franchisors are required to comply with provisions such as, a disclosure document containing information about the franchise system prior to signing the franchise agreement, a seven day cooling-off period after signing the agreement and the use of alternative dispute resolution methods. Despite the increase in regulation the franchising sector in Australia has continued to grow with the number of franchises increasing from 560 in 1998 to over 1100 in 2008 (Frazer \& McCosker, 1999; Frazer \& Weaven, 2002, 2004; Frazer, Weaven, \& Wright, 2006, 2008). Notably a higher level of franchising per capita in Australia exists compared to the United States (Frazer, 2000; True, Pelton, \& Strutton, 2003; Wright \& Frazer, 2004).

\section{Method}

No previous review of Australian franchising research has been published. Hence, a range of search methods and databases were utilised in order to gather as much Australian literature as possible. Articles were available from previous research. A number of digital database indices (including Google and Google Scholar) were searched highlighting more articles and government funded/based studies. These articles and studies were referenced checked to ascertain further research in the area of Australian franchising. A brief summary of each study was written. A broad analysis of the studies was then undertaken in an attempt to form research or method based categories. These can be found in Table 1. As the analysis progressed categorical determination became increasingly difficult as the disparate nature of research and method became apparent. This process is explained in the next section.

Table 1: Overview of Research in Australia

\begin{tabular}{|c|c|c|c|c|c|}
\hline $\begin{array}{l}\text { Time } \\
\text { Period }\end{array}$ & Research & Focus & Problems & Advantage & \\
\hline $\begin{array}{l}\text { 1980s- } \\
\text { early } \\
1990 \mathrm{~s}\end{array}$ & $\begin{array}{l}\text { Initial } \\
\text { exploratory } \\
\text { and } \\
\text { descriptive } \\
\text { work (some } \\
\text { census focus) }\end{array}$ & $\begin{array}{l}\text { Attributes; } \\
\text { industry size, firm } \\
\text { size, geographical } \\
\text { spread, turnover } \\
\text { Data focused on } \\
\text { sector growth } \\
\text { attributes }\end{array}$ & $\begin{array}{l}\text { Small sample } \\
\text { size, } \\
\text { unrepresentative }\end{array}$ & $\begin{array}{l}\text { Some larger } \\
\text { samples gather } \\
\text { in the early } \\
1990 \mathrm{~s}\end{array}$ & $\begin{array}{l}\text { Bureau of Industry Economics, } \\
\text { 1981, Australian Bureau of } \\
\text { Statistics (ABS), 1994; Bureau } \\
\text { of Industry Economics, 1990; } \\
\text { Department of Industry } \\
\text { Technology and Commerce, } \\
\text { 1992b; Franchisors Association } \\
\text { of Australia, 1992; Franchisors } \\
\text { Association of Australia and } \\
\text { New Zealand, 1992; Small } \\
\text { Business Development } \\
\text { Corporation Western Australia, } \\
1992\end{array}$ \\
\hline $\begin{array}{l}1990- \\
2007\end{array}$ & $\begin{array}{l}\text { Disparate } \\
\text { exploratory } \\
\text { research }\end{array}$ & $\begin{array}{l}\text { Motivations to } \\
\text { expand } \\
\text { internationally; } \\
\text { high performing } \\
\text { franchisees, } \\
\text { service quality; } \\
\text { survival; fee } \\
\text { structure } \\
\end{array}$ & $\begin{array}{l}\text { Snapshot } \\
\text { approach to } \\
\text { research rather } \\
\text { than coherent or } \\
\text { longitudinal } \\
\text { work being } \\
\text { pursued. }\end{array}$ & $\begin{array}{l}\text { Evidence base } \\
\text { being built } \\
\text { increasing } \\
\text { general } \\
\text { knowledge. }\end{array}$ & $\begin{array}{l}\text { Welch, 1989, 1990; McCosker, } \\
\text { 1989, 1992, 1996; Merrilees \& } \\
\text { Frazer, 2006; Frazer, Merrilees, } \\
\text { \& Wright, 2007; Huang \& Phau, } \\
\text { 2009; Williams, 1992; Frazer, } \\
\text { 2001; Frazer, 1998; Frazer \& } \\
\text { McCosker, 1995/6; Frazer \& } \\
\text { Perry, 1998 }\end{array}$ \\
\hline 1998 & $\begin{array}{l}\text { Code of } \\
\text { Conduct } \\
\text { Introduced }\end{array}$ & $\begin{array}{l}\text { Effect of its } \\
\text { introduction }\end{array}$ & & $\begin{array}{l}\text { Recommendatio } \\
\text { ns for future } \\
\text { improvements }\end{array}$ & $\begin{array}{l}\text { Frazer 2000; Terry, 2001 Frazer } \\
\& \text { Terry, 2002; Lim \& Frazer, } \\
\text { 2002; Frazer \& Winzar, 2005; } \\
\text { Weaven \& Frazer, 2003; Rao \& } \\
\text { Frazer, 2005, 2006; Inma \& } \\
\text { Debowski, 2006 }\end{array}$ \\
\hline $\begin{array}{l}\text { From } \\
1998 \\
\text { onwards }\end{array}$ & Census style & $\begin{array}{l}\text { Franchising } \\
\text { Australia surveys } \\
\text { began }\end{array}$ & & $\begin{array}{l}\text { Reliable source } \\
\text { of Australian } \\
\text { data }\end{array}$ & $\begin{array}{l}\text { Frazer \& McCosker, 1999; } \\
\text { Frazer \& Weaven, 2002, 2004; } \\
\text { Frazer et al., 2006, 2008; } \\
\text { McCosker \& Frazer, 1998 }\end{array}$ \\
\hline
\end{tabular}




\begin{tabular}{|c|c|c|c|}
\hline $\begin{array}{l}2000- \\
2010\end{array}$ & $\begin{array}{l}\text { Focus on } \\
\text { structure }\end{array}$ & $\begin{array}{l}\text { Multiple units; co- } \\
\text { branding; } \\
\text { governance; } \\
\text { gender issues }\end{array}$ & $\begin{array}{l}\text { Weaven \& Frazer, 2007a, } \\
\text { 2007b; Wright \& Frazer, 2007; } \\
\text { Wright, Frazer, \& Merrilees, } \\
\text { 2007; Weaven \& Herington, } \\
\text { 2007; Weaven, Isaac, \& } \\
\text { Herington, } 2007\end{array}$ \\
\hline
\end{tabular}

\section{Overview of the Research}

Early exploratory and descriptive studies reflected the embryonic development of franchising in the 1980s. At that time the sector came under review, comparing self-regulation with mandatory regulation. Hence a logical conclusion is that studies were generally initiated by government or sector interests to characterise relevant franchising activities. Data were mainly limited to sector growth attributes providing support for increased economic value. For example, the FAA report identified that the largest industry involved in franchising was the fast food and restaurant industry (28 percent). That 34 percent of franchisors commenced franchising within one year of commencing operations. The total proportion of franchise units increased from 84 percent to 85 percent during 1990-1991. 80 percent of franchises charged a royalty fee of approximately 3 percent of turnover. Over 74 percent of franchisors charged an advertising levy of 2 to 3 percent (Franchisors Association of Australia, 1992). Alternatively the FAANZ report identified an increase of franchised units from 85 to 88 percent during the period 1991-1992 (Franchisors Association of Australia and New Zealand, 1992). The Department of Industry, Technology and Commerce also gathered comprehensive statistics on the number of units, turnover, franchise fees, employment, franchising imports/exports, and operational variables such as franchise manuals. An increase on company owned units was found (Department of Industry Technology and Commerce, 1992a). Finally the Australian Bureau of Statistics surveyed all Australian businesses thought to be franchisors with emphasis placed on growth and size of the franchising sector (Australian Bureau of Statistics, 1994). State based surveys replicated (perhaps unnecessarily) features of the national surveys focussing on employment and dispute data (Small Business Development Corporation Western Australia, 1992). These studies can be largely characterised as lacking depth. While limited in scope and validity, these studies established a trend, to highlight further research to explore and/or describe the sector in a more robust context. Thus, the Franchising Australia Surveys commenced in 1998 with the latest delivered in 2008 (Frazer \& McCosker, 1999; Frazer \& Weaven, 2002, 2004; Frazer et al., 2006, 2008; McCosker \& Frazer, 1998). These studies remain census based and provide mainly descriptive data on the status of business format franchising including the size of the franchising sector, total number of franchisors, franchise units, growth rate, contribution to employment, franchising trends, industries categories, total sales of the sector, system age/size, structure, geographical distribution, and the nature of disputes/conflict resolution methods and international expansion trends. These surveys remain a significant source of reliable but limited data.

A range of disparate exploratory studies in the early 1990s gained limited insight into specific aspects of franchising and subsequently lacked continuity and worth for further research. Motivations to expand internationally were found to have strong bias to culturally similar locations (McCosker, 1992, 1996; Welch, 1989, 1990) Attributes and characteristics of high performing franchisees were compared to United Kingdom and Canada data (McCosker, 1989). The disparity is emphasised by the time elapsed before further research (in the 2000s) determined the variability of performance among franchisees (Merrilees \& Frazer, 2006). Inconsonant research continued from the mid 1990s, for example, insights into franchise fee structure and activity (Frazer, 1998; Frazer \& McCosker, 1995/6; Frazer \& Perry, 1998); strategic reasons justifying the recent emergence of multiple unit franchising arrangements within Australia from the perspective of the franchisor (Weaven \& Frazer, 2007a, 2007b); motivations to co-brand in a franchise system revealed franchisor risk averse behaviour to the use of externally owned brands (Wright \& Frazer, 2007; Wright et al., 2007); a contrast of governance structures between mature franchise systems utilising a strong pluralist system (extensive company owned and franchise outlet mix) and immature systems favouring high levels of franchising (Weaven 
\& Herington, 2007); motivational incentives driving franchising choice from the female franchisee's perspective (Weaven et al., 2007); and, an analysis of service quality in franchise systems highlighted cooperative franchisees providing higher levels of performance and satisfaction levels (Huang \& Phau, 2009).

Alternative, but also disparate, research streams identified higher survival rates of franchise systems when compared to independently owned small businesses (a longitudinal study from 1973 to 1990) (Williams, 1992). Comparatively motives for discontinuing a franchising strategy from the franchisor's perspective were then identified with some links found between industry sector and discontinuance (Frazer, 2001). A similar theme of research conducted in the 2000s focussed on franchisees exiting systems in order to continue operating independently highlighting the ineffectiveness of contractual remedies and sporadic high levels of franchisee dissatisfaction (Frazer et al., 2007).

Explanatory and conceptual research emerged in the mid 1990s but with limited evidence of continuity from earlier scoping studies. Again, these studies lack consistent identifiable themes. For example, research examined linkages between a firm's growth and the use of Franchise Advisory Councils (FACs) but results indicated a significant difference its' perceived effectiveness. (McCosker, Frazer, \& Pensiero, 1995). Support for a contracting cost framework was identified in a comparison between resource constraints and transaction cost economics in Australian franchise systems (Frazer \& Stokes, 1997).

Research then fixated on the introduction of the Franchising Code of Conduct and its subsequent effects. The use of advisors prior to franchisee purchase, increased disclosure information, franchisee selection and initial and ongoing support provided by franchisors were identified as factors which impacted upon franchisee satisfaction levels post purchase (Hing, 1996); early sector maturity occurred with older and larger franchises experiencing greater levels of disruption (Frazer, 2000, 2001); the internet was identified as a potential problem with encroachment in franchisee territories by franchisors resulting in a number of legal cases (Terry, 2001); mature franchise systems were more likely to experience franchise terminations than younger systems and support for a relational approach to termination (Frazer \& Terry, 2002); limitations of the Code were related to its ambiguity, cost, time consumption and applicability to all franchise sector participants, but was generally defined as beneficial (Lim \& Frazer, 2002); causes of franchisee failure and exits from franchise systems were identified with system size, investment and degree of conflict related to the incidence of negative franchisee exits (Frazer \& Winzar, 2005).

Not until 2003 did research diversify into other areas. For example, the construction of a conceptual model explaining multiple unit adoption in Australia (Weaven \& Frazer, 2003); the adoption of internet technologies in Australian franchise systems with the major uses of franchisor websites providing information to consumers as a means of attracting potential franchisees (Rao \& Frazer, 2005, 2006); and, characteristics of Australian franchise firms were determined utilising hierarchical cluster analysis and discriminant analysis of four defined groups suggesting franchises are heterogeneous with characteristics used to predict group performance (Inma \& Debowski, 2006).

\section{Conclusions and Future Research Directions}

This paper identified broad areas of research in franchising over a 30 year period within Australia. A gradual shift from a narrow focus on descriptive and scoping studies in the 1980s to a profusion of studies in a variety of areas from 2000 on e.g. international experience, motivations, governance, quality of service to name but a few were identified.

In terms of method most early studies utilised census surveys evolving into a case based approach and subsequently more advanced quantitative methods were incorporated as the sector matured. 
Sample sizes gradually increased as early descriptive studies gathered pace with the scale of geographical coverage. However, it is possible to characterise the work as fragmented and dominated by a 'snap-shot' approach to the research as evidenced by an almost complete dearth of longitudinal work. The franchising sector clearly lends itself to longitudinal studies. Franchising is easily identified and accessible both centrally (through the Franchise Council of Australia) as well as industry specific codification. This is an excellent opportunity for researchers to go beyond a static census based approach. This potential redirection of method lends itself to prescriptive questions such as "how should.....franchising be done?" rather than the purely descriptive approaches of "how is....franchising done?" highlighted in this paper. A paradigmatic shift might appraise franchising activities from alternate perspectives (Elango \& Fried, 1997).

Research has largely focussed on census style data to identify franchise sector size and trends. Post the introduction of the Franchise Code of Conduct, a spate of research emerged with limited contribution to theoretical foundations supporting franchise system evolution and development. These reflections on regulatory influence and the cause and resolution of intra-system conflict dominate the literature of the past decade. However, while franchise sector participants (franchisors, regulators and the legal fraternity) determine the value of these studies the ongoing direction of academic research has limitations. These limitations can be identified by the tenet caveat emptor and the confinement of methods for franchisee recruitment and selection utilised by franchisors by the Code (caveat venditor - let the seller be aware) and identified in the Franchising Australia surveys (Frazer et al., 2006, 2008). This is tantamount to insularity in the research to date which has kept the development of franchising research on a separate trajectory to the broader SME literature.

If research in this area is to advance there is need to (a) acknowledge the interface with other research domains in SME and entrepreneurship research. For example UK studies highlight significant links between franchising and small business (Kirby \& Watson, 1999; Stanworth, Stanworth, Watson, Purdy, \& Healeas, 2004) (b) systematically extend the range of issues which are the subject of franchise research e.g. including theoretical foundations for the more complex governance structures developing in Australia, franchise adoption of brand portfolios, mergers and acquisition and prospective active investor behaviour (Wright \& Frazer, 2007) (c) make a concerted effort to begin longitudinal studies in order to better understand change over time (d) promote studies which have a sectoral focus in order to improve knowledge and understanding at that level of analysis (e) increase the representation of cross-cultural research in the volume of work being undertaken. These are the initial gaps in the research which, having been identified in this paper, are the starting points for what should now be addressed by researchers in the field. 


\section{References}

Australian Bureau of Statistics. (1994). Franchising Sector Survey Results - 1994. Canberra: Department of Industry, Science and Technology.

Australian Bureau of Statistics (ABS). (1994). Franchising Sector Survey Results - 1994. Canberra: Department of Industry, Science and Technology.

Bureau of Industry Economics. (1990). Small Business Review 1988-1989. Canberra: Australian Government Printing Services.

Corones, S. (1999). Competition law in Australia (2nd ed.). Sydney: LBC information services.

Department of Industry Technology and Commerce. (1992a). Franchising in Australia 1989-1991. In Franchising - Australia and Abroad (pp. 5-36). Canberra: DITAC.

Department of Industry Technology and Commerce. (1992b). Franchising in Australia 1989-1991. Canberra: DITAC.

Elango, B., \& Fried, V. (1997). Franchising Research: A Literature Review and Synthesis. Journal of Small Business Management, 35(3), 68-81.

FCA. (2007). What is franchising? Retrieved 15/06/2003, Franchise Council of Australia, from http://www.franchise.org.au/scripts/cgiip.exe/WService=FCAWWW/ccms.r?PageId=10095

Franchisors Association of Australia. (1992). National Survey. Parramatta: FAA. (FAA o. Document Number)

Franchisors Association of Australia and New Zealand. (1992). Franchising in the Economy. Parramatta: FAANZ. (FAANZ o. Document Number)

Frazer, L. (1998). Motivations for franchisors to use flat continuing franchise fees. Journal of Consumer Marketing, 15(6), 587-597.

Frazer, L. (2000). Assessing franchising sector maturity: Australian evidence. Australasian Marketing Journal, $8(2), 33-46$.

Frazer, L. (2001). Causes of disruption to franchise operations. Journal of Business Research, 54, $227-234$.

Frazer, L., \& McCosker, C. (1995/6). An Exploratory Analysis of the Use of Franchise Fees in Australian Franchises. Small Enterprise Research: The Journal of SEAANZ, 4(1\&2), 78-94.

Frazer, L., \& McCosker, C. (1999). Franchising Australia 1999 : a survey of franchising practices and performance. Toowoomba: University of Southern Queensland.

Frazer, L., Merrilees, B., \& Wright, O. (2007). Power and control in the franchise network: an investigation of ex-franchisees and brand piracy. Journal of Marketing Management, 23(9/20), 1037-1054.

Frazer, L., \& Perry, C. (1998). Innovative Fee Structures by Australian Franchisors. The Journal of SEEANZ, 6(1), 10-30.

Frazer, L., \& Stokes, D. (1997). Franchising Operational Units in Australia. Franchising Research: An International Journal, 2(1), 32-42.

Frazer, L., \& Terry, A. (2002). Factors affecting franchise agreement termination: Lessons for the franchising sector. Journal of Small Business Strategy, 13(1), 105-116.

Frazer, L., \& Weaven, S. (2002). Franchising Australia 2002 Survey. Brisbane: Griffith University.

Frazer, L., \& Weaven, S. (2004). Franchising Australia 2004 Survey. Brisbane: Griffith University.

Frazer, L., Weaven, S., \& Wright, O. (2006). Franchising Australia 2006 Survey. Brisbane: Griffith University.

Frazer, L., Weaven, S., \& Wright, O. (2008). Franchising Australia 2008 Survey. Brisbane: Griffith University.

Frazer, L., \& Winzar, H. (2005). Exits and expectations: why disappointed franchisees leave. Journal of Business Research, 58, 1534-1542.

Hing, N. (1996). An empirical analysis of the benefits and limitations for restaurant franchisees. International Journal of Hospitality Management, 15(2), 177-187.

Huang, Y., \& Phau, I. (2009). Mapping the profiles of franchisees: Getting to know the black sheep, rough diamonds, whingers and best buddies. Direct Marketing: An International Journal, 2(4), 221-238. 
Inma, C., \& Debowski, S. (2006). Analysis of franchise performance through use of a typology: An Australian Investigation. Singapore Management Review, 28(2), 1-30.

Kirby, D., \& Watson, A. (1999). Franchising as a small business development strategy: a qualitative study of operational and "failed" franchisors in the UK. Journal of Small Business and Enterprise Development, 6(4), 341-349.

Lim, J., \& Frazer, L. (2001). Introducing franchising regulation: An analysis of the Australian Franchising Code of Conduct. Paper presented at the International Society of Franchising Conference, Las Vegas.

Lim, J., \& Frazer, L. (2002). Introducing Franchising Regulation: An Analysis of the Australian Franchising Code of Conduct. Journal of Marketing Channels, 10(2), 39-56.

McCosker, C. (1989). The profile and performance of franchisees. (Accounting Research Study 11), 1-26.

McCosker, C. (1992). Franchise Education Regulation and Assistance: Report on Study Tour of USA and UK, January-February 1991. Canberra: Australian Federal Government.

McCosker, C. (1994). The Growth and Ongoing Development of Franchising as a Business Method: The Australian Experience. Paper presented at the The Culture of Business: The Russian and World Experience, International Conference.

McCosker, C. (1996). Franchising in Asia: An Overview of Selected Target Markets. Paper presented at the Annual Society of Franchising.

McCosker, C., \& Frazer, L. (1998). Franchising Australia 1998: A survey of franchising practices and performance. Toowoomba: University of Southern Queensland.

McCosker, C., Frazer, L., \& Pensiero, D. (1995). An Exploration of Franchise Advisory Councils: Expectations and Relationships. Paper presented at the International Society of Franchising.

Merrilees, B., \& Frazer, L. (2006). Entrepreneurial franchisees have hidden superior marketing systems. Qualitative Market Research: An International Journal, 9(1), 73-85.

O.E.C.D. (1994). Competition Policy and Vertical Restraints. Paris: Organisation for Economic Cooperation and Development.

Rao, S., \& Frazer, L. (2005). The use of Internet-based technologies in Australian franchise systems: A preliminary study. The Journal of Internet Business, 1(2).

Rao, S., \& Frazer, L. (2006). Australian franchisor websites: moving towards network behaviour. Journal of Theoretical and Applied Electronic Commerce Research, 1(1), 56-64.

Small Business Development Corporation Western Australia. (1992). Franchising in Western Australia. In Franchising - Australia and Abroad: Supplement to the Franchising Task Force Final Report (pp. 5563). Queanbeyan: Better Printing Service.

Stanworth, J., Stanworth, C., Watson, A., Purdy, D., \& Healeas, S. (2004). Franchising as a Small Business Growth Strategy: A Resource-Based View of Organisational Development. International Small Business Journal, 22(6), 539-559.

Terry, A. (1991). Policy Issues in Franchise Regulation: Australia. Journal of International Franchising \& Distribution Law, 77-90.

Terry, A. (1996). The regulation of franchising in Australia: Reviews, roundabout and Realpolitik. Paper presented at the Society of Franchising Conference, Hawaii.

Terry, A. (2001). The E-Business Challenge to Franchising. Paper presented at the 10th Annual Conference of the International Society of Franchising.

Terry, A., \& Giugni, D. (2005). Business \& the law (4th ed.). Southbank, Victoria: Thomson Learning.

True, S., Pelton, L., \& Strutton, D. (2003). The Lost Frontier in Entrepreneurship: Aggregation, Saturation and Decimation of the Franchising Channel. Journal of Marketing Channels, 11(1), pp. 79-89.

Weaven, S., \& Frazer, L. (2003). Predicting Multiple Unit Franchising: A Franchisor and Franchisee Perspective. Journal of Marketing Channels, 10(3/4), 53-82.

Weaven, S., \& Frazer, L. (2007a). Expansion Through Multiple Unit Franchising: Australian Franchisors Reveal their Motivations. International Small Business Journal. 
Weaven, S., \& Frazer, L. (2007b). Mature franchise systems use multiple unit franchising to leverage learning economies and sustain systemwide growth. Asia Pacific Journal of Marketing, 19(2), 107-126.

Weaven, S., \& Herington, C. (2007). Factors influencing governance choice and human resource management within services franchising networks. Journal of Management and Organisation, 13, 126-144.

Weaven, S., Isaac, J., \& Herington, C. (2007). Franchising as a path to self-employment for Australian female entrepreneurs. Journal of Management and Organisation, 13, 345-365.

Welch, L. (1989). Diffusion of franchise system use in international operations. International Marketing Review, 6(5).

Welch, L. (1990). Internationalisation by Australian Franchisors. Asia Pacific Journal of Management, 7(2), $101-121$

Williams, A. (1992). Data on franchised firms and their owner/managers in Australia (1973-1990). Canberra: Australian Federal Government.

Wright, O., \& Frazer, L. (2004). The future of franchising in a mature sector: An Australian perspective. Paper presented at the International Society of Franchising, Las Vegas.

Wright, O., \& Frazer, L. (2007). A multiple case analysis of franchised co-branding. Australasian Marketing Journal, 15(2), 68-80.

Wright, O., Frazer, L., \& Merrilees, B. (2007). McCafe: The McDonald's Co-branding Experience. Journal of Brand Management, 14(6), 442-458. 